JPPI (Jurnal Penelitian Pendidikan Indonesia)

ISSN Cetak: 2477-8524-ISSN Online: 2502-8103

http://jurnal.iicet.org | DOI : https://doi.org/10.29210/02018253

Volume 4 Nomor 2, 2018, hlm 104-110

Info Artikel:

Diterima: 29/11/2018

Direvisi: 30/11/2018

Dipublikasikan: 30/12/2018

Dipublikasikan oleh:
Indonesian Institute for Counseling, Education and Therapy (IICET)

\title{
Implementation of children kinesthetic intelligence development activities in kindergarten
}

Shinta Safenia Anisah ${ }^{1}$, Nurhafizah ${ }^{2}$, RivdaYetti $^{3}$

Universita Negeri Padang

\begin{abstract}
The purpose of this study was to plan, implement, and evaluate the activities carried out by the teacher in developing the kinesthetic intelligence of children in the first kindergarten of the Padang governor's office. The method used in this study is descriptive with a qualitative approach. Data collection techniques in this study were carried out through observation, interviews, and dokumentation. The data analysis techniques of data in this study using triangulation techniques. The results of this study indicate that the implementation of the kinesthetic intelligence development activities of children in the first kindergarten of the Padang governor's office has been maximazed. First, seen from the semester program made by the teacher, the weekly learning implementation plan (RPPM), the plan of implementing daily learning (RPPH). Second, the implementation of the methods used varies, including direct practice methods, demonstration method, and methods of assigning assignments. Third, evaluations used are observation, performance and anecdotal records. It can be concluded that the planning, implementation, and evaluation of teachers can develop children's kinesthetic intelligence and the achievements obtained include the runner up of the plate dance competition in the city of Padang, Batok dance, movements and songs etc.
\end{abstract}

Keywords: kinesthetic intelligence, kindergarten

This is an open access article distributed under the Creative Commons Attribution License, which permits unrestricted use, distribution, and reproduction in any medium, provided the original work is properly cited. (C2018 by author

\section{PENDAHULUAN}

Anak usia dini adalah sosok individu yang sedang menjalani suatu proses perkembangan dan pertumbuhan yang sangat pesat. Usia dini merupakan kesempatan baik bagi anak untuk belajar. Proses perkembangan manusia secara utuh telah dimulai sejak janin dalam kandungan ibunya dan memasuki usia emas (the golden age) sampai usia enam tahun. Usia $0-6$ tahun merupakan masa peka bagi anak karena perkembangan kecerdasannya mengalami peningkatan yang sangat signifikan. Untuk mengembangkan dan menstimulasi setiap perkembangan anak maka disediakanlah suatu wadah dalam jenjang pendidikan, yang disebut dengan Pendidikan Anak Usia Dini (PAUD), Nurhafizah \& Kosnin (2016).

Dalam UU No. 20 tahun 2003, tentang Sistem Pendidikan Nasional disebutkan bahwa pendidikan anak usia dini ialah suatu upaya pembinaan yang ditujukan kepada anak sejak lahir sampai dengan usia enam tahun yang dilakukan melalui pemberian rangsangan pendidikan untuk membantu pertumbuhan dan perkembangan jasmani dan rohani agar anak memiliki kesiapan dalam memasuki pendidikan lebih lanjut, Nurhafizah (2018). Selain itu anak juga diharapkan mampu memiliki karakter yang baik dalam kehidupannya (Nurhafizah, 2010).

Rentang anak usia dini dari lahir sampai usia enam tahun adalah usia kritis sekaligus strategis dalam proses pendidikan dan dapat mempengaruhi proses serta hasil pendidikan seseorang selanjutnya artinya pada periode ini merupakan periode kondusif untuk menumbuh kembangkan berbagai kemampuan, kecerdasan, bakat, kemampuan fisik, kognitif, bahasa, sosial emosional dan spiritual, sesuai dengan keunikan dan tahap-tahap perkembangan yang dilalui oleh anak usia dini (Suyadi \& Ulfah, 2013 ; Nurhafizah, 2012). 
Pendidikan sangat penting bagi anak usia dini dalam rangka mengembangkan segala potensi atau kemampuan yang dimilikinya. Seorang anak mempunyai potensi yang sangat besar untuk berkembang. Kecerdasan atau dalam bahasa inggris disebut dengan intelligence berarti kesempurnaan dalam perkembangan akal budi seperti ketajaman pikiran. Kecerdasan juga berhubungan dengan kapasitas seseorang untuk memahami dan mengaplikasikan ilmu pengetahuan yang mereka dapatkan. Manusia memiliki banyak bentuk kecerdasan yang disebut dengan kecerdasan mejemuk atau multiple intelligence, Sefrina (2013). Kecerdasan majemuk ditemukan oleh Howard Gardner seorang ahli psikologi, menurut Howard Garnerd dalam Suyadi (2014) menyatakan bahwa ada banyak jenis intelligence khusus atau kerangka pikiran, adapun jenis kecerdasan yang dimaksud adalah kecerdasan linguistik, logika-matematika, visual, kinestetik, musikal, interpersonal, intrapersonal, naturalis dan eksistensial. Salah satu yang akan dibahas dari kecerdasan tersebut adalah kecerdasan kinestetik.

Kecerdasan kinestetik adalah kemampuan yang berhubungan dengan kemampuan gerak tubuh dan kemampuan motorik tubuh. Kecerdasan kinestetik merupakan salah satu aspek yang mesti dikembangkan sedini mungkin sebagaimana yang dinyatakan Nurhafizah \& Kosnin (2015) bahwa Taman kanak-kanak merupakan salah satu bentuk penyelenggaraan pendidikan yang menitikberatkan pertumbuhan dan perkembangan fisik motorik. Sebagaimana kita ketahui bahwa di dalam kehidupan sehari-hari kita tidak pernah lepas dari yang namanya gerak. Sejak dari masa kanak-kanak gerak dipahami sebagai sebuah sarana untuk mendukung kelangsungan hidup manusia itu sendiri seperti gerak berjalan, berlari, jongkok-berdiri, duduk atau meloncat, dan beserta kompleksitasnya. Pendapat Suyadi (2014) mengatakan bahwa kecerdasan kinestetik adalah kemampuan untuk menggabungkan antara fisik dan pikiran sehingga menghasilkan gerakan yang sempurna. Menurut Gallahue dalam Samsudin (2008) menyatakan bahwa untuk mengambangkan pola-pola gerak anak sebaiknya dilakukan melalui aktivitas-aktivitas seperti menari, permainan, olahraga, dan senam dimana aktivitas-aktivitas tersebut masuk ke dalam wilayah pendidikan jasmani.

Kecerdasan kinestetik merupakan kelebihan yang dimiliki seseorang lebih dari yang lainnya dalam mengolah gerakan motorik tubuhnya. Siswa yang menonjol dalam kecerdasan ini selalu mengekspresikan dirinya melalui gerakan-gerakan tubuhnya (Nurhafizah, 2011). Ia memilliki keseimbangan tubuh yang baik. Dengan berinteraksi melalui ruang disekelilingnya, ia dapat mengingat dan memproses setiap informasi yang diterimanya dalam konteks belajar, Samsudin (2008). Menurut Sefrina (2013) Faktor-faktor yang dapat mempengaruhi kecerdasan kinestetik adalah 1) asupan nutrisi atau asupan gizi pada anak, 2) latihan dan stimulasi yang berkaitan dengan pergerakan tubuh.

Stimulasi kinestetik atau gerak diberikan melalui rangsangan gerak tubuh yang kemudian akan direspons anak dengan gerakan tubuh pula. Karena hampir setiap gerakan melalui perintah otak, kecuali gerak refleks tubuh yang merupakan gerakan spontan otot-otot tubuh tanpa adanya perintah dari otak. Oleh karena itu, bila rangsangan kinestetik diberikan kepada anak dengan melibatkan gerakan tubuh, sel-sel otaknya semakin banyak terstimulasi, dan seluruh potensi kecerdasan kinestetik anak akan tumbuh dan berkembang, Acandra (2010). Jadi secara tidak langsung kecerdasan kinestetik anak dapat berkembang dengan baik melalui berbagai kegiatankegiatan fisik yang menarik dan menyanangkan agar anak tertarik dalam melakukan aktivitas fisik tersebut.

\section{METODE}

Jenis penelitian ini adalah penelitian deskriptif dengan menggunakan pendekatan kualitatif. Menurut Arikunto (2010) penelitian deskriptif merupakan penelitian yang dimaksudkan untuk mengumpulkan informasi mengenai status atau gejala yang ada, yaitu keadaan gejala menurut apa adanya pada saat penelitian dilakukan. Seiring dengan itu Menurut Moleong (2013) mengatakan bahwa penelitian kualitatif adalah penelitian yang bermaksud untuk memahami fenomena tentang apa yang dialami oleh subyek penelitian misalnya perilaku, persepsi, motivasi, tindakan, dan lain-lainya. Dalam penelitian deskriptif ini dengan pendekatan kualitatif data yang dikumpulkan berbentuk kata-kata, menggambarkan apa adanya tanpa memberikan perlakuan dan juga tidak berbentuk angka.

Penelitianinidilakukan di Taman kanak-kanak Pertiwi 1 Kantor Gubernur Padang yang beralamat di Jalan Koto Tinggi No 2A, Kelurahan Jati Baru Kecamatan Padang Timur Kota Padang. Waktu pelaksanaanya pada semester genap tahun ajaran 2018/2019. Instrumen penelitian adalah alat yang digunakan untuk mengukur variable penelitian. Sugiyono (2012) menyatakan instrumen penelitian adalah suatu alat yang digunakan mengukur fenomena alam maupun sosial yang diamati. Instrumen yang dipakai untuk mengumpulkan data penelitian ini yaitu format observasi, format wawancara, catatan lapangan, dan dokumentasi. 
Sumber data penelitian ini yaitu subyek penelitian dan informan penelitian. Subyek penelitian ini adalah murid dan guru di Taman Kanak-kanak Pertiwi 1 Kantor Gubernur Padang dan informan penelitiannya adalah guru dan kepala sekolah sebagai informan utama di Taman Kanak-kanak Pertiwi 1 Kantor Gubernur Padang. Teknik pemilihan informan yang digunakan dalam penelitian ini adalah purposive sampling. Menurut Sugiyono (2011) Purposive sampling adalah teknik pengambilan sampel sumber data dengan pertimbangan-pertimbangan tertentu misalnya orang tersebut dianggap paling tahu, paling mampu dan sebagainya. Untuk memperoleh data dalam penelitian ini, tentunya diperlukan adanya teknik pengumpulan datadigunakan terdiri dari observasi, wawancara dan dokumentasi.

Pada penelitian ini teknik keabsahan data yang digunakan adalah triangulasi. Menurut Moleong (2012) triangulasi adalah teknik pemeriksaan data dengan memanfaatkan sesuatu hal lain di luar data itu untuk keperluan data pengecekan atau sebagai pembanding terhadap data itu. Teknik triangulasi yang peneliti gunakan dalam penelitian ini adalah triangulasi dengan sumber. Menurut Patton dalam Moleong (2012) triangulasi dengan sumber berarti membandingkan dan mengecek balik derajat kepercayaan suatu informasi yang diperoleh melalui waktu dan alat yang berbeda. Dalam hal ini berarti penelti membandingkan hasil yang didapat dengan cara membandingkan data hasil pengamatan atau observasi dengan data hasil wawancara dan dokumentasi. Data hasil wawancara kemudian dicek dengan observasi dan dokumentasi.

\section{HASIL}

Berdasarkan temuan dilapangan mengenai Pelaksanaan Kegiatan Pengembangan Kecerdasan Kinestetik Anak Di Taman Kanak-kanak Pertiwi 1 Kantor Gubernur Padang dengan teknik pengumpulan data melalui observasi, wawancara, dan dokumentasi, didapatkan hasil sebagi berikut:

\section{Perencanaan Pelaksanaan Kegiatan Kecerdasan Kinestetik}

Berdasarkan hasil observasi dan wawancara yang sudah dilakukan oleh peneliti, perencanaan pelaksanaan kegiatan dikelas B Taman Kanak-kanak Pertiwi 1 Kantor Gubernur Padang disusun berdasarkan kurikulum yang ada, hal pertama yang dilakukan guru adalah membuat program semester dikelompokkan berdasarkan tema dan subtema yang akan digunakan selama semester 1 dan semester 2 pada awal tahun ajaran baru.

Selanjutnya membuat Rencana Pelaksanaan Pembelajaran Mingguan yang disusun berdasarkan program semester yang sudah dirancang sebelumnya, RPPM dibuat sebagai acuan dalam membuat RPPH. Guru menyusun RPPH setiap harinya. RPPH terdiri dari kegiatan awal, kegiatan inti, istirahat dan kegiatan akhir. RPPH dirancang berpedoman kepada tema, subtema, dan indikator perkembangan anak.

\section{Pelaksanaan Kegiatan Pengembangan Kecerdasan Kinestetik}

Berdasarkan hasil observasi dan wawancara yang sudah dilakukan oleh penelitipelaksanaan kegiatan kecerdasan kinestetik anak terdiri dari kegiatan yang direncanakan dan kegiatan yang tidak direncanakan.

\section{Kegiatan yang direncanakan}

Pada hari Senin, 5 Februari 2018, kegiatan yang dirancang ibu S adalah menyusun balok bentuk dangau. Kegiatan dilakukan didalam kelas. Kegiatan tersebut dapat melatih kecepatan anak pada pengembangan kecerdasan kinestetik.Pada hari Rabu, 7 Februari 2018, kegiatan yang dirancang ibu M adalah melompat dengan ketinggian 30-50 cm, Kegiatan dilakukan didalam kelas. Kegiatan tersebut dapat melatih keseimbangan anak pada pengembangan kecerdasan kinestetik. Pelaksanaan kegiatan pengembangan kecerdasan kinestetik anak pada hari Senin, 12 Februari 2018 yang dirancang ibu S adalah melompat keluar masuk simpai. Kegiatan dilakukan diluar kelas. Kegiatan tersebut dapat melatih kecepatan anak pada pengembangan kecerdasan kinestetik.

Pelaksanaan kegiatan pengembangan kecerdasan kinestetik anak pada hari Senin, 19 Februari 2018, kegiatan yang dirancang ibu $\mathrm{M}$ adalah berjalan diatas papan titian. Kegiatan dilakukan diluar kelas. Kegiatan tersebut dapat melatih keseimbangan anak pada pengembangan kecerdasan kinestetik. Selanjutnya pada hari Selasa, 20 Februari 2018, kegiatan yang dirancang ibu S adalah lari estafet. Kegiatan dilakukan diluar kelas. Kegiatan tersebut dapat melatih kecepatan anak pada pengembangan kecerdasan kinestetik.Pelaksanaan kegiatan pengembangan kecerdasan kinestetik pada hari Selasa, 27 Februari 2018 kegiatan yang dirancang ibu $\mathrm{M}$ adalah melempar dan menangkap bola kecil. Kegiatan dilakukan didalam kelas. Pada kegiatan ini dapat melatih koordinasi dalam keterampilan fisik anak pada pengembangan kecerdasan kinestetik anak. Pada hari Selasa, 27 Februari 2018, kegiatan yang dilakukan adalah kegiatan sanggar tari. Kegiatan tersebut dilakukan oleh ibu SY. Kegiatan tersebut dapat melatih kelenturan, keseimbangan, dan koordinasi dalam keterampilan fisik anak pada pengembangan kecerdasan kinestetik. 
Berdasarkan uraian diatas dapat disimpulkan bahwa pelaksanaan kegiatan pengembangan kecerdasan kinestetik yang dilakukan ibu S kelas B1 dan ibu M kelas B3 serta ibu SY sebagai guru sanggar tari di Taman Kanak-kanak Pertiwi 1 Kantor Gubernur Padang dapat melatih pengembangan kecerdasan kinestetik anak.

\section{Kegiatan yang tidak direncanakan}

Berdasarkan observasi yang peneliti lakukan pada hari Rabu, 14 Februari 2018, kegiatan yang dilakukan adalah kegiatan memanah. Kegiatan memanah diadakan pada lembaga Persatuan Panahan Indonesia atau PERPANI. Kegiatan tersebut dapat melatih koordinasi dalam keterampilan fisik anak pada pengembangan kecerdasan kinestetik.

\section{Metode Pengembangan Kecerdasan Kinestetik}

Berdasarkan hasil observasi dan wawancara yang sudah dilakukan oleh peneliti, metode pengembangan kecerdasan kinestetik di kelas B1 dan B3 serta Sanggar Tari di Taman Kanak-kanak Pertiwi 1 Kantor Gubernur Padang, menggunakan metode demonstrasi, metode praktek langsung, dan metode pemberian tugas.Penggunaan metode pembelajaran disesuaikan dengan media dan kegiatan yang sedang dilakukan.

Pada kegiatan tanggal 5 Februari 2018 kelas B1 dengan ibu S, guru menggunakan metode yang sesuai dengan perencanaan yang dibuat sebelumnya, guru menggunakan metode pemberian tugas. Metode pemberian tugas dilakukan untuk kegiatan menyusun balok bentuk dangau. Selanjutnya Pada tanggal 7 Februari 2018 kelas B3 dengan ibu M, guru menggunakan metode praktek langsung. Metode praktek langsung dilakukan untuk kegiatan melompat dengan ketinggian 30-50cm.Pada tanggal 12 Februari 2018 kelas B1 dengan ibu S, guru menggunakan metode yang sesuai dengan perencanaan yang dibuat sebelumnya, guru menggunakan metode praktek langsung. Metode praktek langsung dilakukan untuk kegiatan melompat keluar masuk simpai.

Pada kegiatan kecerdasan kinestetik tanggal 19 Februari 2018 kelas B3 dengan ibu M, guru menggunakan metode pemberian tugas. Metode pemberian tugas dilakukan untuk kegiatan berjalan diatas papan titian. Selanjutnya dalam kegiatan pengembangan kecerdasan kinestetik anak pada tanggal 20 Februari 2018 kelas B1 dengan ibu S, guru menggunakan metode demonstrasi. Metode demonstrasi dilakukan untuk kegiatan lari estafet. Pada tanggal 27 Februari 2018 kelas B3 dengan ibu M dan ibu SY guru pada sanggar tari, menggunakan metode demonstrasi. Metode demonstrasi dilakukan untuk kegiatan melempar dan menangkap bola kecil serta tari pada anak.

Untuk terlaksananya proses belajar mengajar yang baik harus adanya metode-metode yang cocok diberikan guru pada anak. Metode yang digunakan oleh guru disesuaikan dengan media yang dipakai dalam pengembangan kecerdasan kinestetik anak.

\section{Media Pengembangan Kecerdasan Kinestetik}

Berdasarkan observasi dan wawancara pada tanggal 5 Februari sampai 3 Maret 2018 di Taman Kanakkanak Pertiwi 1 Kantor Gubernur Padang, dalam pengembangan kecerdasan kinestetik anak guru menggunakan media yang telah dirancang sebelumnya dan didalam RPPH. Media yang digunakan menarik perhatian anak, sehingga anak mampu menyampaikan kegiatan yang disampaikan guru.

Pada tanggal 5 Februari 2018, ibu S menggunakan media balok-balok persegi panjang sebanyak enam buah. Kegiatan yang dilakukan yaitu menyusun balok bentuk dangau dengan cara anak berlari membawa balok yang telah diacak kemudian menyusunnya kembali dengan bentuk dangau atau pondok petani. Selanjutnya guru menggunakan media persegi pada tanggal 7 Februari 2018, ibu M mengunakan media kotak persegi sebanyak 3 buah. Kegiatan yang dilakukan yaitu melompat dengan ketinggian 30-50 cm dengan cara anak melompati satu persatu kotak yang telah disusun guru sampai ujung.Pada tanggal 12 Februari 2018, ibu S menggunakan media simpai sebanyak 6 buah. Kegiatan yang dilakukan yaitu melompat keluar masuk simpai dengan cara anak dibagi menjadi 2 kelompok dan pada setiap kelompok telah disusun simpai sebanyak 3 buah. Kemudian anak berlomba untuk melompati simpai dan yang tercepat sampai kembali maka kelompok tersebut yang menang.

Pada pelaksanaan Kegiatan pengembangan kecerdasan kinestetik pada tanggal 19 Februari 2018, ibu M menggunakan media papan titian. Kegiatan yang dilakukan yaitu berjalan dengan seimbang menggunakan papan titian dengan cara anak merentangkan tangan dan berjalan dengan seimbang diatas papan titian sampai ujung. Selanjutnya pada tanggal 20 Februari 2018, ibu S menggunakan media balok panjang bulat seperti tongkat. Kegiatan yang dilakukan yaitu anak anak berlari membawa tongkat secara estafet kepada temannya sampai akhir. Pada tanggal 27 Februari 2018, ibu M menggunakan media bola kecil. Kegiatan yang dilakukan yaitu melempar dan menangkap bola kecil dengan cara guru melempar kepada anak bola kecil tersebut dan anak 
menangkapnya. Selanjutnya pada tanggal 27 Februari 2018, ibu SY menggunakan media batok dan tape, kegiatan yang dilakukan yaitu tari dengan cara guru memandu anak dalam menari.

Berdasarkan uraian diatas dapat disimpulkan dalam pelaksanaan kegiatan pengembangan kecerdasan kinestetik anak di Taman Kanak-kanak Pertiwi 1 Kantor Gubernur Padang terlihat pemilihan media pembelajaran sudah cukup baik. Media yang digunakan sudah sesuai dengan rancangan RPPH sebelumnya. Media yang digunakan dapat melatih keterampilan gerak tubuh anak dan kemudian kegiatan yang dilakukan guru menggunakan media tersebut sangat menarik bagi anak sehingga anak fokus, semangat dan sangat senang dalam melaksanakan kegiatan pengembangan kecerdasan kinestetik

\section{Evaluasi Pengembangan Kecerdasan Kinestetik}

Berdasarkan hasil observasi dan wawancara yang sudah dilakukan oleh peneliti dalam pelaksanaan kegiatan pengembangan kecerdasan kinestetik anak di Taman Kanak-kanak Pertiwi 1 Kantor Gubernur Padang, guru telah melakukan evaluasi pembelajaran guna mengetahui sampai mana pengetahuan anak tentang kecerdasan kinestetik.

Evaluasi pembelajaran dilakukan guru dengan cara observasi langsung pada anak. Guru mengadakan evaluasi pada saat kegiatan pembelajaran berlangsung, guru memperhatikan dengan jeli mana anak yang bisa mengerjakan kegiatan sendiri. Dengan ikut sertanya guru mendampingi anak dalam melakukan kegiatan, guru akan memperoleh hasil evaluasi.

Selain itu guru juga melihat perkembangan anak unjuk kerja saat kegiatan berlangsung, pada saat proses pembelajaran berlangsung guru dapat menilai anak yang bisa mengikuti kegiatan dengan baik dan mana yang tidak, sehingga guru bisa langsung membimbing anak yang masih perlu bantuan guru.

Selain itu guru juga mengevaluasi setiap aspek perkembangan anak, mulai dari anak datang sampai anak pulang ke sekolah, kemudian sebelum pulang guru melakukan evaluasi kembali tentang kegitan yang dilakukan anak pada hari itu dengan tenya jawab kepada anak. penilaian dilakukan dengan cara observasi dengan teknik catatan anekdot.

\section{PEMBAHASAN}

Berdasarkan analisis data yang telah peneliti lakukan, maka peneliti akan mendeskripsikan pembahasan data yang diperoleh. Hasil penelitian yng telah diperoleh akan digunakan untuk mendapatkan hasil yang diharapkan. Kemudian direlevansikan dengan relevansi-relevansi yang terkait dengan pembahasan tersebut. Adapun pembahasannya sebagai berikut:

\section{Perencanaan Pelaksanaan Kegiatan Pengembangan Kecerdasan Kinestetik}

Temuan yang diperoleh dari hasil observasi dan wawancara yang peneliti lakukan tentang perencanaan kegiatan kecerdasan kinestetik anak yaitu dimulai dari merancang Program Semester, Rencana Pelaksanaan Pembelajaran Mingguan (RPPM), dan Rencana Pelaksanaan Pembelajaran Harian (RPPH).

Menurut Wahyni, dkk (2015) Rencana Pelaksanaan Pembelajaran Harian (RPPH) merupakan acuan untuk mengelola kegiatan bermain dalam satu hari. RPPH disusun dan dilaksanakan oleh guru. Format RPPH tidak harus baku, tetapi memuat komponen-komponen yang ditetapkan. Komponen RPPH terdiri atas: (1) identitas program, (2) materi, (3) alat dan bahan, (4) kegiatan pembukaan, (5) kegiatan inti, (6) kegiatan penutup, dan (rencana penilaian).

Berdasarkan hasil temuan observasi dan wawancara tentang perencanaan kegiatan pengembangan kecerdasan kinestetik anak yang dilakukan guru sudah berjalan dengan baik, dimulai dari program semester, RPPM dan RPPH. Dapat dilihat dalam perencanaan pembelajaran kecerdasan kinestetik oleh guru yaitu guru membuat perencanaan harian sehari sebelum pelaksanaan dilakukan.

\section{Pelaksanaan Kegiatan Pengembangan Kecerdasan Kinestetik}

Berdasarkan hasil temuan dilapangan bahwa kegiatan pengembangan kecerdasan kinestetik anak usia dini telah sesuai dengan perencanaan yang telah dirancang oleh guru sebelumnya. Hasil penelitian pada kegiatan kecerdasan kinestetik yang peneliti dapatkan dari observasi, wawancara dan dokumentasi pada kegiatan pengembangan kecerdasan kinestetik anak diantaranya adalah kegiatan menyusun balok, melompat, berjalan di atas papan titian, melempar dan menangkap bola, dan lari estafet dan kegiatan sanggar tari anak. 
Sejalan dengan pendapat Umami, dkk (2016) Permainan estafet merupakan permainan yang dilakukan seccara beregu, dimana setiap regu terdiri dari empat orang pelari, setiap pelari mempunyai peran masingmasing dalam permainan.

\section{Metode Pengembangan Kecerdasan Kinestetik}

Berdasarkan hasil temuan observasi dan wawancara di kelas B1 dan B3 di Taman Kanak-kanak Pertiwi 1 Kantor Gubernur Padang, adapun metode yang digunakan guru dalam kegiatan pengembangan kecerdasan kinestetik yaitu, metode demonstrasi, metode praktek langsung dan metode pemberian tugas. Pendapat Sutikno (2013) menyatakan metode demonstrasi adalah metode membelajarkan dengan cara memperagakan dalam proses pembelajaran untuk memperjelas pengertian konsep dan memperhatikan cara melakukan sesuatu.

\section{Media Pengembangan Kecerdasan Kinestetik}

Berdasarkan hasil temuan di lapangan bahwa terdapat beragam media yang digunakan dalam kegiatan pengembangan kecerdasan kinestetik anak usia dini di Taman Kanak-kanak Pertiwi 1 Kantor Gubernur Padang. Media yang digunakan sesuai dengan kegiatan pengembangan yang dilakukan, dan media yang digunakan dapat melatih keterampilan gerak tubuh anak khususnya kecerdasan kinestetik serta menumbuhkan perasaan senang pada anak dan menarik perhatian anak.

Hasil penelitian tersebut didukung oleh teori para ahli yaitu Menurut Susanto (2017) menyatakan jenis media dan sarana dan prasarana untuk pembelajaran PAUD adalah tape recorder, TV, VCD, komputer, balok, baju profesi, rumah-rumahan, peralatan masak, peralatan dokter, alat musik, bahan-bahan alam (seperti biji, daun dan kayu), botol, gelas, ember, kertas warna, jepitan baju, gunting, lem, krayon, manik-manik, puzzle, meja, kursi, papan tulis, buku-buku, dan gambar-gambar (binatang, tubuh, buah-buahan, angka, huruf). Disamping media fisik tersebut, dapat juga menggunakan media lainnya seperti suara, tubuh, dan gerakan untuk pembelajaran di kelas, yang sesuai dengan materi yang dibahas.

\section{Evaluasi Kegiatan Pengembangan Kecerdasan Kinestetik}

Bentuk penilaian yang dilakukan oleh guru dalam kegiatan pengembangan kecerdasan kinestetik anak di Taman Kanak-kanak Pertiwi 1 Kantor Gubernur Padang. Guru melakukan evaluasi dengan cara observasi, yaitu dengan melihat proses anak mengerjakan kegiatan yang diberikan guru, unjuk kerja anak dan catatan anekdot. Sejalan dengan Pendapat Yus (2015) menyatakan bahwa observasi atau pengamatan merupakan penilaian yang dilakukan dengan mengamati prilaku dan aktivitas anak dalam suatu waktu atau kegiatan.

Guru juga melihat perkembangan kecerdasan kinestetik anak melalui unjuk kerja saat kegiatan berlangsung, pada saat proses pembelajaran berlangsung guru dapat menilai anak yang bisa mengikuti kegiatan dengan baik dan mana yang tidak, sehingga guru bisa langsung membimbing anak yang masih perlu bantuan guru. Selain itu guru juga melakukan penilaian setiap aspek perkembangan anak, mulai dari anak datang sampai anak pulang ke sekolah.

\section{KESIMPULAN}

Berdasarkan penelitian yang dilakukan di Taman Kanak-kanak Pertiwi 1 Kantor Gubernur Padang, maka dapat disimpulkan hasil penelitian ini yaitu, perencanaan kegiatan yang dilakukan oleh guru dalam kegiatan pengembangan kecerdasan kinestetik dirancang oleh guru dan kepala sekolah pada awal tahun ajaran baru seperti Pogram semester (Prosem) kemudian guru-guru membuat Rencana Pelaksanaan Pembelajaran Mingguan (RPPM) dan Rencana Pelaksanaan Pembelajaran Harian (RPPH). RPPH berpedoman pada tema, subtema dan indikator perkembangan anak yang dibuat sehari sebelum kegiatan dilaksanakan sesudah anak pulang.

Metode yang digunakan guru yaitu metode praktek langsung, metode demonstrasi, dan metode pemberian tugas. Dengan melalui metode pembelajaran yang bervariasi kegiatan perkembangan kecerdasan kinestetik anak dapat berkembang dengan baik dan sesuai dengan yang direncanakan. Media yang digunakan dapat melatih keterampilan gerak tubuh anak dan menarik perhatian anak.

Evaluasi atau penilaian yang dilakukan guru dalam kegiatan kecerdasan kinestetik dengan melalui observasi yang dilakukan pada proses kegiatan, unjuk kerja dan catatan anekdot, dengan tersebut guru dapat

\section{DAFTAR RUJUKAN}

Acandra,. (2010, Mei). Ragam Stimulasi Gerak Biar Anak Cerdas. Kompas

Arikunto, Suharsimi. (2010). Manajemen Penelitian. Jogjakarta: Rineka Cipta 
Moleong. (2012). Metodologi Penelitian Kualitatif. Bandung: PT Remaja Rosdakarya

Moleong. (2013). Metodologi Penelitian Kualitatif (Cetakan Ketiga Puluh Satu). Bandung: PT Remaja Rosdakarya

Nurhafizah. 2010. Urgensi Pendidikan Karakter dalam Pendidikan Anak Usia Dini. Proceeding Seminar Nasional Aktualisasi Pendidikan Karakter Bangsa. 1

Nurhafizah. (2011). Mengembangkan Karakter Anak Usia Dini melalui Seni Tari.PGPAUD UNY Yogyakarta

Nurhafizah. (2012). Peranan Senam Otak (Brain Gym) dalam Pemusatan Perhatian (Atensi) Anak Usia Dini Pada Kegiatan Permbelajaran. $1^{\text {st }}$ International Conference on Early Childhood Education. 1

Nurhafizah. Kosnin, Azlina Mohd. (2015). Implementasi Permainan Tradisional Indonesia di Taman Kanakkanak Kota Padang. Jurnal Pedagogi 15 (FIP UNP), 85-93.

Nurhafizah. Kosnin, Azlina Mohd. (2016). The Development of Children's Social-Emotional Competence: ACase Study in UNP's Labschool Kindergarten, Padang Indonesia. International conference on Early Childhood Education 58: Atlantis Press.

Nurhafizah, N. 2017. Strategi Pengembangan Kemampuan Sains Anak Taman Kanak-kanak Di Koto Tangah, Padang. Jurnal Pedagogi 3 (3b) UM Surabaya

Samsudin. (2008). Pembelajaran Motorik di Taman Kanak-Kanak. Jakarta: Prenada Media Group

Sefrina, Andin. (2013). Deteksi Minat Bakat Anak: Optimalkan 10 Kecerdasan Pada Anak. Yogyakarta: Media Pressindo

Sugiyono. (2011). Metodologi Penelitian Kuantitatif, Kualitatif, dan R\&D. Bandung: Alfabeta

Sugiyono. (2012). Memahami Penelitian Kualitatif. Bandung: Alfabeta

Suryana, Dadan. (2013). Pendidikan Anak Usia Dini (Teori dan Praktik Pembelajaran). Padang: UNP Press

Susanto, Ahmad. (2017). Pendidikan Anak Usia Dini (Konsep dan Teori). Jakarta: PT Bumi Aksara

Sutikno, Sobry. (2013). Belajar dan Pembelajaran. Lombok: Holistica

Suyadi. (2014). Teori Pembelajaran Anak Usia Dini. Bandung: PT Remaja Rosdakarya

Suyadi \& Maulidya Ulfah. (2013). Konsep Dasar PAUD. Bandung: PT Remaja Rosdakarya

Umami, Aulia dkk. (2016). Peningkatan Kecerdasan Kinestetik Anak Melalui Permainan Estafet. Jurnal Ilmiah Potensia. 1 (1), 15-20

Undang-Undang RI Nomor 20. (2003). Tentang Sistem Pendidikan Nasional. Jakarta: Sinar Grafika

Wahyuni, Mareta dkk. (2015). Penyusunan Rencana Pelaksanaan Pembelajaran PAUD. Jakarta: Direktorat pembinaan Pendidikan Anak Usia Dini

Yus, Anita. (2015). Penilaian Perkembangan Belajar Anak Taman Kanak-kanak. Jakarta: Kencana 